\title{
The Study and Analysis on the Students' Attitude to BLOG Based on the Mathematical Statistics
}

\author{
Fang Xie \\ School of Art and Design, Jiangsu University of Technology, Changzhou, China \\ x_ie_fang@126.com
}

Keywords:college students, microblog, investigation and analysis, $\mathrm{T}$ test

\begin{abstract}
In recent years, microblog has experienced a rapid development in China and has made a great impact on the society. Now more and more college students are using microblog, with the popularity of microblog in the college students, it has produced a certain influence on the information communication, college students' interpersonal communication, campus public opinion, it also has brought new opportunities and challenges to the college students' ideological and political education. This paper, by using SPSS statistical analysis to analyse college students' attitude to the microblog and grasping the influence of microblog on college students, new methods and new ways of college students' ideological and political development are deployed.
\end{abstract}

\section{Introduction}

Microblog is a platform which can combine the users' information sharing, dissemination and accessing together, through the WEB, WAP and various individual communities that were established by the clients, users can update information and realize the real-time share within 140 words.

In recent years, microblog has experienced a rapid development in China and has made a great impact on the society. Now more and more college students are using microblog, but the influences produced by the microblog on daily life, interpersonal communication, climate of learning, especially the opportunities and challenges to the college students' ideological and political education mode are still uncertain. This paper, by using SPSS statistical software and integrating all sorts of factors, new ways for college students' ideological and political education are explored in order to establish the idea of active educational function of the microblog, construct the ideological and political education platform, guide the trend of public opinion, and grasp new trends which were caused by the microblog.

\section{The data collection and model foundation}

A. Data collection

This survey issued 104 questionnaires, 104 were returned, and all of them were valid, the recovery rate was $100 \%$. The questionnaires were issued on line, the original recovery data was stored in an Excel document, read the processed date by using the SPSS software then the SPSS data file was obtained. Freshman accounted for 9.62\% (10 people) sophomore accounted for $26.92 \%$ ( 28 people ), junior accounted for $60.58 \%$ ( 63 people ), senior accounted for $2.88 \%$ (3 people).

B. The Analysis Model

In this paper, the SPSS software is adopted for analysis, it is mainly used for frequency analysis, correlation analysis and the two independent $\mathrm{T}$ test.

1) Frequency analysis

Frequency is a case number that is taken from one variable upon each variable. Frequency analysis will help a lot in the understanding of the variables' value distribution.

2) Correlation analysis

Correlation analysis is a study to determine whether there are some dependencies among the study phenomena; it also probes into the related direction and degree of the dependent phenomena. Correlation analysis is a kind of statistical method to study the correlation of the random variables 
The Person simple correlation coefficient is used in this survey.

The mathematical model is:

$$
r_{x y}=\frac{\sum_{i=1}^{n}\left(x_{i}-\bar{x}\right)\left(y_{i}-\bar{y}\right)}{\sqrt{\sum_{i=1}^{n}\left(x_{i}-\bar{x}\right)^{2} \sum_{i=1}^{n}\left(y_{i}-\bar{y}\right)^{2}}}
$$

3) Two independent $T$ test

The so-called independent samples mean that the two samples are independent without any correlation. The two samples will accept the same measurement respectively. The main purpose of this test is to know whether there is a significant difference between them.

The mathematical model is:

$$
t=\frac{\bar{X}_{1}-\bar{X}_{2}}{\sqrt{S_{c}\left(\frac{1}{n_{1}}+\frac{1}{n_{2}}\right)}} \quad S_{c}^{2}=\frac{\left(n_{1}-1\right) S_{1}^{2}+\left(n_{2}-1\right) S_{2}^{2}}{n_{1}+n_{2}-2}
$$

\section{Analysis procedures and results}

\begin{tabular}{|c|c|c|c|c|c|}
\hline \multicolumn{6}{|c|}{ Have you registered a microblog? } \\
\hline & & Frequency & Percentage & Effective percentage & $\begin{array}{c}\text { Cumulative } \\
\text { percentage }\end{array}$ \\
\hline \multirow[t]{3}{*}{ Valid } & 1 & 103 & 99.0 & 99.0 & 99.0 \\
\hline & 2 & 1 & 1.0 & 1.0 & 100.0 \\
\hline & Total number & 104 & 100.0 & 100.0 & \\
\hline
\end{tabular}

A.Frequency analysis of the registered microblog situation

Then the SPSS software frequency analysis is adopted to show the rate students' registered microblogs, the data above shows that among the 104 objects, 99.9\% of college students have registered microblogs, and only one of them does not register the microblog. The frequency analysed data shows that basically all college students have registered microblog. Now microblog is very popular among students, it has already been a part of the students' daily life, interpersonal relationship, study and other various aspects,it is also the tool for students to contracting with the outside world.

\begin{tabular}{|c|c|c|c|c|c|}
\hline \multicolumn{6}{|c|}{ how much time do you spend on the microblog per day } \\
\hline & & Frequency & Percentage & Effective percentage & $\begin{array}{l}\text { Cumulative } \\
\text { percentage }\end{array}$ \\
\hline \multirow[t]{5}{*}{ Valid } & 30 minutes & 27 & 26.0 & 26.0 & 26.0 \\
\hline & 1 hour & 32 & 30.8 & 30.8 & 56.7 \\
\hline & 1-3 hours & 32 & 30.8 & 30.8 & 87.5 \\
\hline & More than 3 hours & 13 & 12.5 & 12.5 & 100.0 \\
\hline & Total number & 104 & 100.0 & 100.0 & \\
\hline
\end{tabular}

$B$.Frequency analysis of the average time spend on the microblog per day of the college students

According to the frequency analysis, $30.8 \%$ of the students spend one hour a day on the microblog, $30.8 \%$ of the students spend 1-3 hours a day on the microblog, 26 percent of college students spend less than half an hour a day on the microblog, $12.5 \%$ of college students spend more than three hours a day on the microblog. Most students spend 1-3 hours on the microblog which may affect the students' learning and living .

\begin{tabular}{|c|c|c|c|c|c|}
\hline \multicolumn{6}{|c|}{ Your visit frequency } \\
\hline & & Frequency & Percentage & Effective percentage & $\begin{array}{l}\text { Cumulative } \\
\text { percentage }\end{array}$ \\
\hline \multirow[t]{4}{*}{ Valid } & Less than once a week & 6 & 5.8 & 5.8 & 5.8 \\
\hline & Once a week & 4 & 3.8 & 3.8 & 9.6 \\
\hline & 2-3 days in a week & 8 & 7.7 & 7.7 & 17.3 \\
\hline & 4-5 days in a week & 12 & 11.5 & 11.5 & 28.8 \\
\hline
\end{tabular}

C.Frequency analysis of the college students microblog access 


\begin{tabular}{|l|l|l|l|l|l|}
\hline & $6-7$ days in a week & 74 & 71.2 & 71.2 & 100.0 \\
\cline { 2 - 5 } & Total number & 104 & 100.0 & 100.0 & \\
\hline
\end{tabular}

According to the SPSS frequency analysis, about $71.2 \%$ of the college students at least visit the microblog once a day, $11.5 \%$ of the students will visit microblog $4-5$ days in a week, $7.7 \%$ of college students will visit microblog 2-3 days in a week, $3.8 \%$ of college students will visit the microblog once a week, $5.8 \%$ of college students will visit the microblog less than once a week. From the data we can know that the frequency of students' visit to microblog is relatively high , most students will visit the microblogging every day,which means microblog has been part of the college students' life.

D.Correlation analysis between visit frequency and time spending

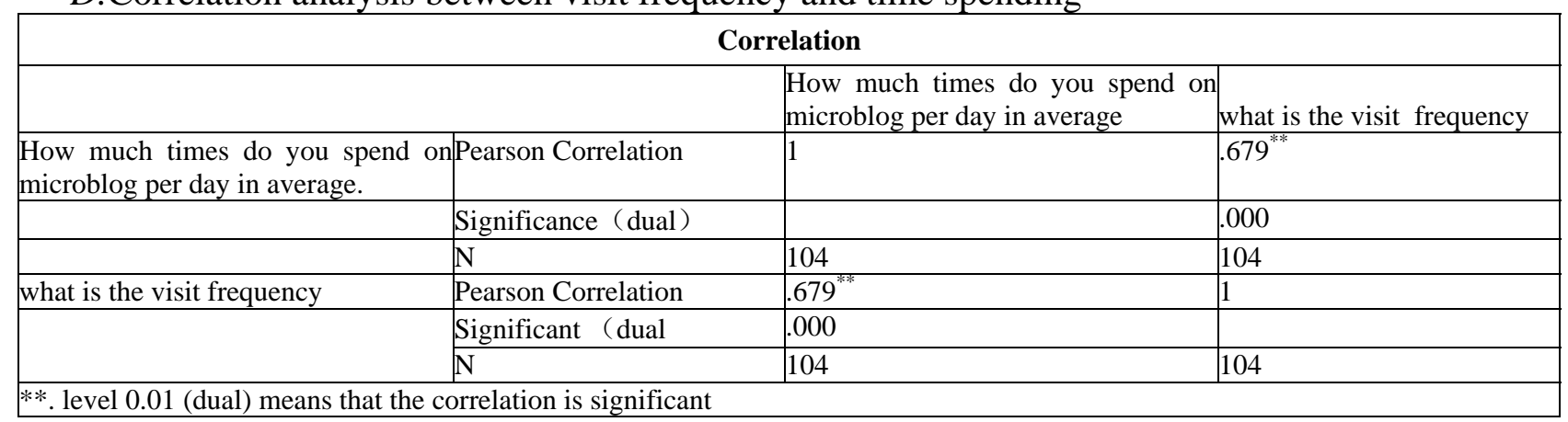

The frequency of visit and time spending on the microblog are significantly correlated on the level 0.01 . The higher the frequency of the college students to visit the microblogging the more time they spend on microblog everyday.

$E$. The frequency analysis of the influence on the worldview and values caused by the mocroblog

\begin{tabular}{|c|c|c|c|c|c|}
\hline \multicolumn{6}{|c|}{ Does the microblog affect your worldview and values? } \\
\hline & & Frequency & Percentage & Effective percentage & $\begin{array}{l}\text { Cumulative } \\
\text { percentage }\end{array}$ \\
\hline \multirow[t]{6}{*}{ Valid } & Agree & 3 & 2.9 & 2.9 & 2.9 \\
\hline & Relatively agree & 28 & 26.9 & 26.9 & 29.8 \\
\hline & Neutral & 57 & 54.8 & 54.8 & 84.6 \\
\hline & Relatively disagree & 14 & 13.5 & 13.5 & 98.1 \\
\hline & Disagree & 2 & 1.9 & 1.9 & 100.0 \\
\hline & Total number & 104 & 100.0 & 100.0 & \\
\hline
\end{tabular}

According to the SPSS frequency analysis, $54.81 \%$ of the students hold the attitude Neutral on the impact of worldview and values produced by the microblog, $26.9 \%$ of the students hold the Relatively agree attitude, $13.5 \%$ of the students hold the Relatively disagree attitude. The Agree attitude is $2.9 \%$ and the Disagree attitude is only $1.9 \%$. The scope and impact of microblog is wide, and the information dissemination and access microblog is very convenient, but every piece of the information is true and reliable, college students should be skeptical about the information that could affect people's worldview and values on the microblog.

F.The influence produced by the microblog on college students

\begin{tabular}{|l|l|l|l|l|l|}
\hline \multicolumn{2}{|c|}{ Have you ever visited the microblog on class? } \\
\hline \multirow{2}{*}{} & Frequency & Percentage & Effective percentage & $\begin{array}{l}\text { Cumulative } \\
\text { percentage }\end{array}$ \\
\hline \multirow{3}{*}{ Valid } & Yes & 70 & 67.3 & 67.3 & 67.3 \\
\cline { 2 - 6 } & No & 34 & 32.7 & 32.7 & 100.0 \\
\cline { 2 - 6 } & Total number & 104 & 100.0 & 100.0 & \\
\hline
\end{tabular}

\begin{tabular}{|l|l|l|l|l|l|}
\hline & \multicolumn{3}{|c|}{ Do you think the microblog will affect your life? } & $\begin{array}{c}\text { Total } \\
\text { number }\end{array}$ \\
\hline & $\begin{array}{l}\text { Favorable, help to learn No } \\
\text { new things }\end{array}$ & $\begin{array}{l}\text { Unfavorable, reduce the learning hours and } \\
\text { effect the attitude of learning }\end{array}$ & \\
others & \\
\hline $\begin{array}{l}\text { Have you ever visited the Yes } 29 \\
\text { microblog on class? }\end{array}$ & No & 41 & 0 & 0 & 70 \\
\hline Total number & 29 & 14 & 15 & 5 & 34 \\
\hline
\end{tabular}

According to the frequency analysis and crossover analysis, we can see that $67.3 \%$ of the students who visit microblog on class believe that visit microblog on class will not affect their learning, on the contrary, they believe that they can learn knowledge from microblog. College student who has a 
good self-discipline and consciousness can use the microblog to learn extracurricular knowledge and focus on the things that he or she is interested in. Microblog also prides a new way of knowledge acquiring for college students.

G.Analysis of the influence on the interpersonal relationship caused by the microblog

Most of the students think microblog is good for friendship for they can meet new friends, however, nearly half of them think that microblog basically has no influence on interpersonal relationship. Microblog as a new kind of Internet media can not only let students to express their emotions, but also allow students to make new friends and expand their connections, which is good for students.

$H$.The significance analysis of the different grades and visit frequency on the microblog

\begin{tabular}{|c|c|c|c|c|c|c|}
\hline \multicolumn{7}{|c|}{ Statistic group } \\
\hline & Grades & & $\mathrm{N}$ & Mean & $\begin{array}{l}\text { Standard } \\
\text { deviation }\end{array}$ & $\begin{array}{l}\text { Standard } \\
\text { error of mean }\end{array}$ \\
\hline \multirow{2}{*}{$\begin{array}{l}\text { Visit } \\
\text { frequency } \\
\text { microblog }\end{array}$} & & Freshman & 10 & 15.40 & 5.680 & 1.796 \\
\hline & on lamensi & Sophomore & 28 & 44.00 & 8.468 & 1.600 \\
\hline
\end{tabular}

\begin{tabular}{|c|c|c|c|c|c|c|c|c|c|}
\hline \multicolumn{10}{|c|}{ Independent sample test } \\
\hline & \multicolumn{2}{|l|}{$\begin{array}{l}\text { Levene test } \\
\text { Of the variance equation }\end{array}$} & \multicolumn{7}{|c|}{ T test of the mean equation } \\
\hline & \multirow[b]{2}{*}{$\mathrm{F}$} & \multirow[b]{2}{*}{ Sig. } & \multirow[b]{2}{*}{$\mathrm{t}$} & \multirow[b]{2}{*}{ df } & \multirow[b]{2}{*}{ Sig.(dual) } & \multirow{2}{*}{$\begin{array}{l}\text { Mean } \\
\text { deviation } \\
\text { value }\end{array}$} & \multirow{2}{*}{$\begin{array}{l}\text { Standard } \\
\text { deviation } \\
\text { value }\end{array}$} & \multicolumn{2}{|c|}{$\begin{array}{l}\text { The } \\
\text { confidence } \\
\text { interval } \\
\text { of } 95 \% \\
\text { low scores }\end{array}$} \\
\hline & & & & & & & & \begin{tabular}{|l} 
Upper \\
limits
\end{tabular} & $\begin{array}{l}\text { Lower } \\
\text { limits }\end{array}$ \\
\hline \multirow[t]{2}{*}{$\begin{array}{l}\text { Visit frequency } \\
\text { microblog }\end{array}$} & $\begin{array}{l}\text { on Assuming variances.319 } \\
\text { is equal }\end{array}$ & .576 & -9.872 & 36 & .000 & -28.600 & 2.897 & -34.476 & -22.724 \\
\hline & $\begin{array}{l}\text { Assuming variances } \\
\text { is unequal }\end{array}$ & & -11.888 & 23.930 & .000 & -28.600 & 2.406 & -33.566 & -23.634 \\
\hline
\end{tabular}

\section{Conclusion}

According to the analyses above, we can see, microblog possesses both the positive effect and the negative effect on college students' learning, interpersonal relationship and life.

A.The positive effects on the ideological and political education caused by the microblog:

(1) broaden students' thoughts and visions.

(2) show emotion and entertain mood.

(3) record life, express themselves.

$B$. The negative effects caused by the microblog on the studengts' psychology cultivation.

(1) affect the college students' interpersonal relationship in the real world

(2) the convenience of disguising of microblog may weaken the college students' self-control ability

(3) the autonomy and independence of microblog may easily caused the autism expansion of college students

C.The exploration of new ideological and political education for college students based on the microblog

(1) face challenges, then build a microblog communication platform.

(2) strengthen the supervision and management on the microblog network system.

How can we make better a use of influences brought by the microblog? The following two points are put forward:

Suggestion 1: according to the investigation and analysis we can see that the microblog has became as another important way of information access. However we must see both the positive and negative effects on college students, figure out the defects of microblog and use it objectively. We also need to pay attention to the veracity of source of information.

Suggestion 2:We should make good use of the high speed, wide information and the strong 
autonomy characteristic of the microblog. Then by using the microblog platform, we can easily select the useful information; get the learning related information and knowledge.

\section{Acknowledgments}

The research was supported by the Ideological and Political Education Research Issue of Jiangsu University of Technology with the project number KYY11024 and the project name Research on the New Media and the Work Innovation of College and University Students' Ideological and Political Education.

\section{References}

[1] Jingui Dai, Challenges and Path of the Ideological and Political Work in the New Media Environment [ J ] , Era of Education ( teaching ), 2011 .07.

[2] Cheng Ding, A Study on the Ideological and Political Education of Agricultural Vocational Colleges in the New Media Environment [J], Neijiang technology, 2010. 12.

[3] Feng Ji,Plight of the Ideological and Political Education in the Network Environment and Countermeasures [ J ] , Education and Vocational , 2011. 23.

[4] Wei Zhang, Study on the Role of New Media in the Ideological and Political Education of College Students [J], Scientific and Technological Information, 2011. 34.

[5] Hui QI, Ziyu QI, Ideological and Political Education in the New Media Environment [J], Beijing Education ( moral ), 2011. 10.

[6] Hong Nie, Study on the Model Innovation of College Students' Party Members Education in the New Media Environment [J], Industry and Technology Forum, 2011. 12.

[7] Hui Xinong, Yifsng Yang, The Application of the Red Resources in College Students' Party Function [J], Jinggangshan University (Social Sciences) , 2011. 01.

[8] Rongjun Wu, Yigang Jiang, On Student Party Members Education in the Sight of the New Media [J], Southern the theory Journal, 2011. 02.

[9] Weilun Zeng, Yan LI, Study on the Red Websites' Spreading Effectiveness of the College Under the New Media Environment [ J ], frontier , 2011. 13. 